\title{
KEMULIAAN DAN PERGESERAN MAKNA GURU
}

\section{Putu Dana Yasa}

\author{
Akademisi Hindu Sulawesi Tenggara \\ Email: putu.dyasa@gmail.com
}

Diterima tanggal 6 Januari 2021, diseleksi tanggal 18 Januari 2021, dan disetujui tanggal 8 Februari 2021

\begin{abstract}
A teacher has a very important role and responsibility for change and improving the quality of students. The responsibility of a teacher must be believed and realized so that the teacher really gives true knowledge in the teaching process. The Hindu view in understanding the meaning of the word "guru" is not limited to a profession as a teaching staff, but in Hindu theological studies "guru" is a person who has a very noble character and position. The glory of a "guru" is contained in various Hindu literature which is also used as a source for Hindus in their efforts to understand religious teachings. "guru" is not just a profession but a person who has spiritual qualifications who are able to lead his students to have ethics and morals. A true "guru" will not be bound by material shackles and even has to be free from everything that is materialism.
\end{abstract}

Keywords: Guru, Theology, responsibility

\begin{abstract}
ABSTRAK
Seorang guru memiliki peranan dan tanggung jawab yang sangat penting terhadap perubahan serta peningkatan kualitas peserta didik. Tanggung jawab seorang guru harus diyakini dan disadari sehingga guru tersebut benar-benar memberikan pengetahuan dengan sungguh-sungguh dalam proses mengajar. Pandangan Hindu dalam memahami arti kata "guru" tidak sebatas sebuah profesi sebagai tenaga pengajar, namun dalam kajian teologi Hindu "guru" merupakan orang yang memiliki sifat dan kedudukan yang sangat mulia. Kemuliaan seorang"guru" tertuang dalan berbagai literatur Hindu yang juga digunakan sebagai sumber umat Hindu dalam upaya memahami ajaran-ajaran agama. "Guru" bukan hanya sebuah profesi melainkan orang yang memiliki kuaifikasi rohani yang mampu mengantarkan siswanya agar memiliki etika dan moral. Seorang "guru" sejati tidak akan terikat oleh belenggu materi bahkan harus lepas dari segala hal yang bersifat materialisme. "Guru" sebagai makhluk yang dianggap mulia harus mampu memuliakan manusia dan terlepas dari kebodohan.
\end{abstract}

Kata Kunci: Guru, Teologi, tanggung-jawab 


\section{PENDAHULUAN}

Peranan guru sebagai salah-satu komponen dalam pendidikan sangat mutlak diperlukan dan memiliki pengaruh besar dalam pengembangan perilaku serta karakter peserta didik. Guru dapat dikatakan menjadi komponen utama sebagai perantara atau media dalam mengantarkan pengetahuan hingga akhirnya sampai pada peserta didik. Seorang guru selain menjadi salah-satu tontonan pembelajaran harus juga menjadi tuntunan dalam mengarahkan setiap manusia khususnya peserta didik untuk keluar dari kegelapan akan kurangnya pengetahuan yang menyebabkan kebodohan. Pengaruh dari kebodohan dan ketidaktahuan merupakan sumber utama penderitaan yang dialami manusia, keterbatasan inilah yang menjadikan manusia harusnya memiliki motivasi untuk terus belajar dan mencari pengetahuan untu menjawab pertanyaan-pertanyaan yang muncul dalam kehidupan ini.

Seiring dengan berjalannya waktu, terjadi perubahan bahkan kesalahpahaman tentang arti sesungguhnya dari "guru". Perubahan ini sangat terlihat secara implisit dan eksplisit sehingga akhirnya menyimpang pada arti serta makna sesungguhnya dari guru tersebut. Posisi guru saat ini hanya dipandang sebagai sebuah profesi guna mendapatkan imbalan sebagai pemenuhan kebutuhannya sebagai manusia. Ketika "guru" yang hendaknya menjadi pelita kegelapan siswa/sisyanya hanya berpikir untuk mengambil keuntungan dari sebuah profesi tentu hal ini sangat bertolak belakang dengan arti serta perilaku guru yang sesungguhnya.

Berbicara perihal "guru" dalam konteks saat ini, seolah-olah kehilangan jejak makna, sebab orang berbicara perihal "guru" saat ini hanya menyangkut yang parsial tidak secara integral. Ada orang yang berbicara tentang "guru" hanya berkaitan dengan tugas-tugas mengajarnya atau tugas mendidiknya. Selanjutnya ada juga yang berbicara tentang "guru" hanya menyangkut masalah gajihnya yang kecil dan kenaikan pangkatnya yang terhambat. Selain itu pula ada yang memberitakan masalah "guru" dari sudut ketidakdisiplinan "guru" seperti tidak menyiapkan persiapan mengajar, malas mengajar dan sebagainya (Donder, 2008:24).

Keberadaan "guru" sejak jaman dahulu hingga saat ini tentu menjadi hal yang sangat penting bagi keberlangsungan hidup umat manusia tanpa terkecuali bagi umat Hindu. Keyakinan Hindu memandang "guru" memiliki kedudukan dan sifat yang sangat mulia. Dalam berbagai kisah yang dituangkan dalam pustaka suci Hindu baik dalam Itihasa dan Purana maupun pustaka suci yang lain, terdapat banyak penjelesan tentang bagaimana seorang "guru sangat dihormati dan diagungkan. Penghormatan pada "guru" dalam keyakinan Hindu tentunya dapat dijadikan tolak ukur bagaimana sesungguhnya kewajiban dari seorang "guru" yang sesungguhnya.

Pengertian "guru" pada dasarnya bukanlah suatu profesi yang mana hanya mengambil keuntungan baik berupa gaji dan tunjangan lainnya sebagai hasil dari kinerjanya sehari-hari. Dalam keyakinan Hindu "guru" lebih mengarah pada orang yang benar-benar memiliki kualifikasi rohani sehingga mampu mengarhkan muridmuridnya agar memiliki karakter dan moral yang baik. seorang "guru" harus mampu mengendalikan diri dari sifat-sifat yang buruk seperti amarah, berbicara kasar, bertidak sewenang-wenang sehingga sesuai dengan apa yang dikatakan oleh Sathya Narayana bahwa secara spiritual "guru" dituntut harus menjadi perwujudan kasih dan kesabaran. 
Beban yang dipikul oleh seorang "guru" merupakan beban yang sangat berat karena tidak hanya menyampaikan pengetahuan yang dimiliki, tetapi menyerahkan secara keseluruhan pengetahuan yang terdapat dalam dirinya sehingga mampu memanusiakan manusia. Hal ini berarti seorang "guru" bukanlah orang sembarangan, bukan orang biasa karena memikul beban yang begitu berat dan bertanggung jawab secara penuh terhadap karakter dari murid yang dimiliki. Dari beratnya beban yang dipikul oleh seorang "guru" sepatutnya "guru" tidak hentihentinya menambah pengetahuan dan terus belajar sehingga nantinya mampu memberikan pengetahuan yang sifatnya selalu berubah seiring dengan perubahan jaman saat ini.

Suparlan (2008: 12) menyatakan bahwa guru dapat diartikan sebagai orang yang tugasnya terkait dalam upaya mencerdaskan kehidupan bangsa dalam semua aspek, naik aspek spiritual, emosional, intelektual, fisikal, maupun aspek lainnya. Namun,Suparlan juga menegaskan bahwa secara formal guru adalah seseorang yang memperoleh surat keputusan baik dari pemerintah maupun pihak swasta untuk mengajar. Dalam pengertian ini terlihat sangat jelas bagaimana pentingnya seorang guru dalam kehidupan khususnya dalam bidang pendidikan baik formal maupun nonformal.

Beberapa pandangan para ahli yang berupaya menjelaskan pengertian seorang guru, lebih banyak penjelasan yang menerangkan bahwa guru hanyalah sebatas profesi semata dalam hal ini adalah profesi sebagai seorang pendidik. Profesi guru menjadi pekerjaan yang amat mulia sehingga guru sering dikatakan sebagai pahlawan tanpa tanda jasa. Jika dilihat kembali lebih jauh istilah pahlawan tanpa tanda jasa ini semakin menyimpang ketika profesi guru hanya menjadi sebuah profesi untuk mendapatkan imbalan baik berupa gaji maupun tunjangan lainnya. Tidak sedikit guru saat ini hanya berupaya memenuhi segala aturan administrasi guna mendapatkan haknya sebagai bagian dari pemerintah maupun swasta agar dapat memenuhi kebutuhan hidupnya tanpa memikirkan lebih jauh tentang masa depan dari murid yang dididiknya. Seorang guru idealnya harus menyadari bahwa dirinya memiliki tanggung jawab penuh terhadap kualitas peserta didiknya. Tanggung jawab ini menjadikan seorang guru harus menyiapkan diri dengan sungguh-sungguh ketika memberikan pembelejaran bagi peserta didiknya, dengan kata lain seorang guru haruslah benar-benar memiliki kemampuan sebagai media para peserta didik agar dapat menerima dan memiliki pengetahuan yang nantinya akan digunakan sebagai pedoman dalam hidupnya.

Selain menjadi bagian terpenting dalam komponen pendidikan, guru juga memiliki kedudukan yang sangat terhormat dihadapan peserta didiknya. Penghormatan kepada seorang guru menjadi kewajiban utama dalam etika seorang peserta didik, namum belakangan ini tidak sedikit terjadi peristiwa yang mengakibatkan keributan dan perkelahian antara guru dan peserta didik. Hal ini artinya telah terjadi penurunan kualitas manusia baik dari guru maupun peserta didiknya, tidak bisa sepenuhnya sepenuhnya peserta didik yang disalahkan dalam hal seperti ini, karena secara tidak langsung ini menjadi sebuah kesalahan dan ketidakmampuan seorang guru mentransfer pengetahuan sehingga menyebabkan terjadinya keributan dan perkelahian.

Penghormatan terhadap guru sangat jelas disampaikan dalam beberapa leteratur Hindu sebagai agama sanatana dharma. Dalam keyakinan Hindu penghormatan ini dituangkan dalam konsep Catur Guru. Selain konsep tersebut 
juga sangat terlihat jelas bagaimana Hindu sangat menghormati seorang guru yang terimplementasi dalam proses diksa dalam Hindu dimana penghormatan seorang sisya terhadap nabe atau gurunya dalam upaya mendapatkan pengetahaun spiritual. Dengan demikian arti kata "guru" semakin diperjelas bahwa "guru" bukan hanya sekedar sebuah profesi semata guna mendapatkan keuntungan, "guru" harus mampu mengarahkan peserta didiknya keluar dan mendobrak kegelapan dan kebodohan yang ada dalam dirinya. Guru harus menyadari bahwa apapun yang dilakukan dalam tugas mulia ini akan dipertanggungjawabkan langsung pada Tuhan.

Dari penjelasan tersebut di atas, dapat dilihat secara sederhana terjadi sebuah pergesaran makna dari kata "guru" dalam hal ini dalam Hindu menganggap "guru" sebagai suatu hal yang sakral dan sangat diagungkan, namun disisi lain dalam realitasnya saat ini, kata "guru" hanya berakhir pada sebuah profesi mendidik dan mengharapkan imbalan terhadap profesi yang dilakukannya tersebut. Terhadap pergeseran inilah penulisan berupaya mengkaji arti kata "guru" ini dalam sebuah kajian teologis, guna mendapatkan kebenaran baik itu kebenaran secara ilmiah maupun kebenaran secara spiritual bahwa "guru" sesungguhnya merupakan perwakilan Tuhan dalam upaya melepas ikatan karma dan mencapai sebuah kebebasan abadi sebagai tujuan akhir umat Hindu.

\section{PEMBAHASAN}

\subsection{Pandangan Umum Tentang Guru dan Pentingnya Pengetahuan}

Perbincangan mengenai kata guru tentu bukanlah hal yang baru, hal ini tentu telah ada sejak lama. Berbagai pandangan para ahlipin muncu guna menyampaikan kebenaran dari apa makna kata guru yang sesungguhnya. Dari berbagai pandangan para ahli ini secara dominan mengarah pada sebuah pengertian bahwa guru merupakan sebuah profesi untuk mencerdaskan bangsa dalam hal ini melalui proses belajar. Guru menjadi media atau perantara pengetahuan agar sampai pada peserta didik sehingga dapat digunakan dalam kebutuhan manusia itu sendiri. Dalam pengertian ini artinya tugas utama seorang guru adalam mendidik dan menyampaikan pengetahuan yang dimilikinya kepada peserta didik.

Roestiyah (2005) bahwa guru dalam mendidik bertugas untuk: 1) menyerahkan kebudayaan pada peserta didik berupa kepandaian, kecakapan, dan pengalaman-pengalaman, 2) membentuk kepribadian peserta didik yang harmonis sesuai dengan cita-cita negara Pancasila, 3) menyiapkan peserta didik menjadi warga negara yang baik sesuai Undang-Undang Pendidikan yang merupakan keputusan MPR No. II tahun 1983, 4) sebagai perantara dalam belajar, dan 5) sebagai pembimbing untuk membawa peserta didik kearah kedewasaan. Dari kelima tugas guru ini sangat jelas terlihat bahwa tugas menjadi seorang guru adalah tugas yang sangat mulia dalam upaya menyiapkan peserta didik berkualitas sehingga nantinya berguna bagi dirinya sendiri maupun berguna bagi bangsa dan negara.

Keterlibatan guru dalam menyiapkan sumber daya manusia yang unggul menjadikan guru sebagai sebuah pekerjaan yang cukup banyak diminati karena dianggap sebagai sebuah pekerjaan yang mulia. Pekerjaan ini yang nantinya akan berperan sangat besar terhadap generasi-generasi muda apakah dapat bersaing dalam kemajuan jaman yang begitu pesat atau malah sebaliknya termakan dengan jaman yang pergerakannya sangat cepat. Kemampuan serta kualifikasi seorang guru 
harusnya menjadi bahan pertimbangan bagi pemerintah dalam menyiapkan sumber daya manusia yang unggul dalam bidan pengetahuan. pendidikan baik dalam tingkat dasar hingga perguruan tinggi harus memiliki guru-guru yang memang berkompeten dalam bidangnya, sehingga dirinya benar-benar mampu menyampaikan kepada peserta didik pengetahuan yang dimiliki.

Guru ataupun tenaga pelajar yang professional tentu menjadi harapan pula bagi peserta didik yang ingin mendapatkan pengetahuan secara utuh, hal ini dikarenakan peserta didik juga memiliki hak untuk mendapatkan pengetahuan guna menjawab segala keraguan terhadap apa yang belum diketahuinya. Menjadi guru yang professional artinya seorang guru benar-benar mampu melaksanakan tugastugasnya sebagai seorang pendidik dan pengajar seperti apa yang tertuang dalam Pancasila, UUD 1945, UUSPN Nomor 20 tahun 2003 dan UUGD Nomor 14 Tahun 2005 yang menyebutkan bahwa guru adalah pendidik professional dengan tugas utama mendidik, mengajar, membimbing, mengarahkan, melatih, menilai, dan mengevaluasi peserta didik pada pendidikan usia dini, jalur pendidikan formal, pendidikan dasar dan menengah.

Tidak dapat dipungkiri jika dilihat secara indryawi seorang guru memang hanya manusia biasa yang tentunya memiliki keterbatasn dalam segala hal, namun dengan gelar atau keberanian dirinya untuk menjadi seorang guru artinya harus sanggup memikul beban dan tanggung jawab yang sangat besar dalam upaya mencerdaskan serta memanusiakan manusia. Mendidik dan mentransfer pengetahuan tentu bukan perkara mudah, apalagi seorang guru memberikan pengetahuan pada orang yang berbeda dengan jumlah yang cukup banyak menjadikan hal tersebut sebagai sebuah tantangan tersendiri bagi seorang guru.

Menjadi guru berarti menyandang dua status sekaligus, yakni professional dan pendidik. Tetapi kedua status ini tidak hanya didasarkan kompetensi dedaktifmetodik saja. Sebab ada ekspektasi sosial yang menjadi cita-cita ideal masyarakat. Sehingga guru professional bukan semata-mata berorientasi mendapatkan pekerjaan dan pendapatan yang layak, namum juga memiliki panggilan jiwa dan kesadaran humanis. Meskipun terdapat banyak pekatihan penigkatan profesi guru dari berbagai jurusan kependidikan, tetapi prosesnya tidak begitu banyak bermakna, hal ini disebabkan cara berpikir guru yang materialistik. Oleh sebab itu, makna guru sebagai sebagai pekerjaan harus digeser pada posisinya sebagai aktor sosial yang saling berdialog dengan realitas sosialnya untuk menemukan berbagai solusi akan persoalan pendidikan (Warsono, 2017).

Pergeseran makna seorang guru harus menjadi hal yang perlu diperhatikan secara serius, guru tidak hanya berupaya memenuhi berbagai administrasi untuk dapat memperoleh tunjangan namun guru harus benar-benar menyadari tugasnya sebagai media sampainya pengetahuan pada siswa. Pergeseran ini menjadi hal yang kembali menambah keyakinan kita bahwa saat ini terjadi penurunan kualitas sumber daya manusia yang dulunya benar-benar melakukan pengabdian, namun saat ini hanya berupaya memenuhi kebetuhan hidupnya. Penurunan sumber daya manusia dalam bidang pendidikan tentunya tidak terlepas dari besarnya kebutuhan manusia dan pesatnya perubahan yang terjadi sehingga tidak sedikit manusia yang terlena dengan perubahan yang terjadi.

Pentingnya pengetahuan saat ini menjadikan benar-benar diperlukan guru yang berkualitas dalam upaya meningkatkan kualitas manusia yang saat ini semakin tidak beretika dan bermoral. Manusia yang diibaratkan terlahir sebagai kertas 
kosong harus dibekali pengetahuan untuk dapat berada dalam jalan kebenaran, hal ini menunjukan pengetahuan menjadi bagian utama yang harus dimiliki oleh setiap manusia. Pengetahuan menjadi sumber dari perkataan dan perbuatan dari seseorang, jika salah mengisi kertas yang kosong terrsebut tentunya akan memberikan coretan yang hanya dapat mengootorinya sendiri.

\subsection{Konsep "Guru" Dalam Kajian Teologi Hindu}

Keterbatasan manusia sebagai makhluk ciptaan Tuhan tentu tidak dapat dihindari, namun upaya untuk mengimbangi keterbatasan tersebut tentu menjadi kewajiban bagi manusia itu sendiri. Salah-satu cara untuk mampu mengimbangi bahkan melampaui ketidatahuan yang disebabkan oleh terbatasnya kemampuan indrya manusia tentu adalah dengan pengetahuan. pengetahuan tentunya dapat diperoleh melalui pembelajarn baik secara formal maupun nonformal. Dalam hal ini pengetahuan akan menjadi benteng utama untuk menjawab segala keraguan dan ketidaktahuan manusia dalam menjalankan karma wasananya. Pengetahuan yang didapatkan manusia selain dari pengalaman hidupnya, juga didapatkan dari seorang guru. Guru memiliki peranan penting dalam mendapatkan sebuah pengetahuan, hal ini dikarenakan guru adalah orang memiliki kemampuan lebih dalam hal menyampaikan pengetahuan yang dimilikinya.

Pandangan "guru" dalam keyakinan Hindu sangat mendasar pada kejadiankejadian peristiwa masa lampau yang tertuang dalam beberapa pustaka suci. Pustaka suci sebagai dasar umat Hindu dalam menjalankan kehidupan tentunya menjadi hal yang sangat diagungkan dan disucikan. "Guru" menjadi sebuah kewajiban yang memiliki beban sangat besar, hal ini dikarenakan tugas "guru" sangat berat untuk mampu mengarahkan peserta didiknya menuju jalan kebenaran sehingga peserta didik lepas dari ketidaktahuan yang menjadi sumber kebodohan dan penderitaan manusia. Dalam hal ini sangat jelas peranan "guru" menjadi sangat penting untuk mampu mambawa manusia terlepas dari penderitaan.

Pustaka Vana Parva menyatakan bahwa umat manusia wajib menghormati lima "guru" yaitu: 1) Agni (Tuhan), 2) Atman (yang memberi kita jiwa), 3) Acarya (yang mengajarkan ilmu pengetahuan suci), 4) Mata (Ibu) dan 5) Pita (Ayah). Selain lima "guru" tersebut terdapat pula empat "guru" yang harus dihormati oleh manusia yaitu: 1) Guru Rupaka (ayah dan ibu, 2) Guru Pengajian (guru di sekolah), 3) Guru Wisesa (Pemerintah) dan 4) Guru Swadhyaya (guru sejati atau Ida Sang Hyang Widhi Wasa). Inilah "guru" yang harus dihormati oleh setiap manusia dalam mejalankan kehidupannya sebagai makhluk yang masi memiliki segala keterbatasan dan ketidaktahuan.

Aripta dalam bukunya yang berjudul "siapakan yang disebut "guru" memaparkan pengertian "guru" sesungguhnya bukanlah sebuah profesi dimana orangnya mengambil keuntungan berupa materu atau gaji atas hasil kerjanya yang diajarkan di sekolah-sekolah baik sekolah formal maupun nonformal. Kata "guru" lebih mengandung pengertian sebagai orang yang memiliki kualifikasi rohani yang mampu mengantar murid-muridnya agar memiliki etika dan moral. Pengertian orang yang mengajarkan pelajaran di sekolah, lebih tepat disebut sebagai "pengajar" bukan "guru". Pengertian "guru" lebih menitiberatkan pada pengertian orang yang telah mampu mengendalikan Tri Guna yaitu sifat sattwam, rajas dan tamas (sifat baik, nafsu agresif dan malas. 
Berdasarkan pandangan Aripta tersebut secara sederhana artinya seorang "guru" idealnya harus mampu mengendalikan dirinya, pengendalian diri bagi seorang "guru" tentu menjadi kewajiban utama karena seorang "guru" akan menjadi pusat perhatian dan segala contoh perilakunya akan dijadikan pedoman bagi peserta didiknya. Pengendalian indrya menjadi modal utama seorang "guru" dalam segala hal. Sebagai tugas yang mulia untuk menyampaikan pengetahuan, tentu sifat dan sikapnyapun harus mencerminkan kemuliaan sehingga "guru" tersebut secara otomatis akan mendapatkan kehormatan yang luar biasa dari peserta didiknya. Pengendalian indrya sesungguhnya telah menjadi pembelajaran dasar bagi setiap umat Hindu yang tuangkan dalam konsep Tri Kaya Parisuda sebagai landasan etika manusia yang terdiri dari manacika (berpikir yang baikk), wacika (berkata yang baik), dan kayika (berbuat yang baik). seorang "guru" harus mampu memahami dan mengamalkan konsep ini sebagai dasar dalam berpikir, berkata dan bertindak pada peserta didik.

Kedudukan seorang "guru" memiliki tingkatan yang sangat tinggi dalam Hindu, hal ini dibuktikan dalam pustaka-pustaka suci yang menguraikan pengambian seorang siswa kepada "guru". Kehormatan yang dimiliki seorang "guru" juga terdapat dalam pustaka suci Mānava Dharmaśāstra II.146 yang menjelaskan sebagai berikut:

Utpādakabrahma dātra

gariyān brahmadah pitā

Brahma Janma hi viprasya

Pretya ce ha ca śáśvatam

(Mānava Dharmaśāstra II.146)

Terjemahan:

Jika dibandingkan antara orang yang memberikan kelahiran kepada seorang anak dan yang memberikan pengetahuan Veda, maka pemberi Veda lebih terhormat dari pada seorang ayah, karena kelahiran yang dilakukan untuk Veda mendapatkan pahala yang abadi dalam hidup di dunia ini dan setelah mati (Pudja dan Rai Sudharta, 2004:66).

Kutipan sloka Mānava Dharmaśāstra II.146 menjelaskan betapa terhormatnya seorang yang mendapatkan kesempatan terlahir untuk memberikan ajaran Veda yang tidak lain itu adalah tugas dari seorang "guru". Kemapanan dalam pengetahuan menjadi sebuah kewajiban oleh setiap orang yang memiliki gelar atau sebutan sebagai "guru". Penghormatan siswapun nantinya akan muncul ketika "guru" tersebut benar-benar memiliki kemampuan dalam memahami pengetahuan secara utuh. Kehormatan seorang guru yang memiliki kualifikasi secara jelas dan mapan menguasai bidang keilmuannya dan juga menguasai ajaran Veda tidak hanya mendapatkan penghormatan dari siswa, bahkan para Dewa pun akan menghormati "guru” tersebut. Hal ini juga tertuang dalam pustaka suci Mānava Dharmaśāstra yang menjelaskan sebagai berikut:

Na tena vrddho bhavati

Yenāsya palitam śirah

Yo vai yuvāpyadhiyānastam

devāh sthaviram viduh

(Mānava Dharmaśāstra II.156)

Terjemahan: 
Seseorang bukanlah dianggap terhormat karena rambutnya sudah uban, tetapi ia yang telah mempelajari Veda, para Dewapun menganggapnya terhormat (Pudja dan Rai Sudharta 2004: 69).

Kutipan sloka Mānava Dharmaśāstra II.156 secara implisit menjelaskan bahwa pengetahuanlah yang menjadi sumber kehormatan bagi setiap manusia yang menjadi kewajiban pula bagi seorang "guru". Pengetahuan yang dimiliki seorang "guru" menjadikan "guru" tersebut mendapat kedudukan yang terhormat baik dari pandangan siswa bahkan para dewa sekalipun. Kemuliaan "guru" ini harusnya menjadi pegangan setiap orang yang memiliki gelar sebagai "guru" untuk dengan sungguh-sungguh memberikan pengetahuan bahkan dirinya untuk dapat mencerdaskan dan memberikan pengetahuan pada siapapun. Pengetahuan menjadi bagian yang terpenting dalam kehidupan manusia sehingga kedudukan manusia sebagai makhluk yang paling sempurna memang pantas untuk didapatkan.

Sebagai seorang "guru" tentu memiliki kemampuan yang lebih dalam berpikir, inilah salah-satu modal penting yang harus dimiliki oleh seorang "guru". Secara simbolis pikiran yang menjadi sumber dari segala yang dilakukan oleh manusia. Secara simbolis, dalam tubuh manusia letak dari pada pikiran disimbolkan pada bagian kepala manusia. Inilah yang menjadi raja dari segala indrya manusia. Kemampuan berpikir inilah yang menjadi pembeda utama antar manusia apakah memiliki pengetahuan atau tidak. Jika memiliki kemampuan yang lebih dalam berpikir, dalam hal ini menguasai pengetahuan maka seorang tersebut memiliki kesempatan untuk menjadi seorang "guru".

Dalam kehidupan yang terjadi pada jaman dahulu, kesempatan belajar dan memiliki pengetahuan hanya dapat diperoleh apabila berasal dari golongan tertentu dalam hal ini adalah sebagai golongan brahmana. Terlahir sebagai brahmana pada jaman dahulu tentunya memiliki kewajiban yang sangat berat, dalam hal ini harus mampu memahami apa yang tertuang dalam pustaka suci dan dapat menjadi tauladan bagi umat manusia. Donder (2007) menjelaskan dalam ajaran yang tertuang baik dalam sruti maupun dalam bentuk upanisad dan juga dalam konsep kosmologi Hindu menyampaikan bahwa struktur anatomi masyarakat secara keseluruhan digambarkan sebagai tubuh manusia. Sebagai tubuh yang utuh maka tubuh tersbut harus terdidi dari beberapa bagian, yaitu: 1) kepala, 2) badan/dada, 3) perut dan 4) tangan dan kaki. Struktur masyarakat yang kompleks atau pluralis seperti itu sering digambarkan sebagai tubuh manusia semesta (manusia kosmis). Analogi tubuh manusia sebagai struktur anatomi masyarakat memiliki keterkaitan pula dengan pengelompokan masyarakat dalam pandangan Hindu yaitu brahmana, ksatrya, vaisya dan sudra. Hal ini tertuang dalam pustaka suci $R g$. Veda sebagai berikut:

Brāhmano'sya mukhamāsidbāhu rājanyah krtah

Śrū tadasya yad vaisyah padbhyām sūdro ajāyata

(Rg. Veda X.90.12)

Terjemahan:

Brahmana lahir dari wajah (kepala)-Nya Tuhan, dan kstriya lahir dari kedua bahu-Nya Tuhan, vaisya dilahirkan melalui perut-Nya Tuhan, dan dari kakiNya lahirah sudra. 
Kutipan sloka dalam Rg. Veda X.90.12 menguraikan bahwa kaum brahmana terlahir dari kepala Tuhan, yang artinya kaum brahmana dalam anatomi tubuh tersebut terletak pada bagian kepala, inilah yang membedakan kemampuan dalam hal pengetahuan yang dimiliki kaum brahmana dengan golongan yang lain. Kaum brahmana yang terletak pada bagian atas dari anatomi tubuh manusia tentu tugasnya tidak berperang, berdangan maupun mengambil pekerjaan yang kasar yang dilakukan oleh gulongan sudra, tugas dari brahma tidak lain adalah belajar dan mengajarkan pengetahun yang dimiliki sehingga umat manusia memiliki kecerdasan dibandingkan dengan makhluk hidup yang lain. Tugas belajar dan mengajar saat ini diwujudkan oleh seorang yang beri gelar "guru", sehingga dalam hal ini "guru" sesungguhnya termasuk ke dalam golongan brahmana (Donder, 2008: 275).

Secara sederhana umat manusia terutama brahmana merupakan perwujudan langsung dari Tuhan untuk dapat menyampaikan pengetahuan yang ada dalam alam semesta. Sebagai wakil Tuhan tentu memiliki tugas yang besar, inilah yang saat ini menjadi beban dari seorang "guru" yang dianggap sebagai bagian dari golongan brahmana yang tidak lain tugas dan kewajibannya adalah belajar dan mengajar. Kewajiban dari golongan brahmana juga tertuang dalam pustaka suci Manava Dharmasastra sebagai pustaka suci yang digunakan sebagai pegangan atau dasar hukum dalam menjalkan kehidupan. Kewajiban brahmana dalam pustaka suci Manava Dharmasastra dijelaskan sebagai berikut:

Adhyāpanam adhyayanam

Yajanam yājanam tahta

Dānampratigraham caiva

Brāhmanānām akalpayat

(Manava Dharmasastra I.88)

Terjemahan:

Kepada para brahamana Tuhan menetapkan kewajibannya untuk: mempelajari dan mengajarkan Veda, melaksanakan upacara kurban untuk dirinya sendiri dan masyarakat umum, memberikan dan menerima dana punia (Pudja \& Rai Sudharta)

Sloka Manava Dharmasastra I.88 ini kembali mempertegas tugas dan kewajiban dari golongan brahmana yang memiliki tugas yang mulia untuk dapat menyampaikan pengetahuan. pengetahuan ini menjadi yadnya yang sangat utama dalam ajaran Hindu, namum kembali harus diingat bahwa menjadi seorang brahmana bukanlah hal yang mudah sehingga hanya orang-orang yang memiliki keteguhan lahir dan batin yang benar-benar mampu menjalankan tugas dari brahmana secara utuh.

Ketika "guru" dikatakan sebagai kaum yang terhormat dan mulia hingga kedudukannya disamakan dengan golongan brahmana tentu menjadi hal yang sangat harus disadari, sehingga pikiran untuk menjadi "guru" bukan hanya ketertarikan terhadap tunjangan dan nilai lain yang diperoleh ketika memenuhi administrasi namun memiliki panggilan jiwa dan keiklasan untuk mengabdikan diri sepenuhnya dan menyadari bahwa siswa yang akan diberikan pengetahuan merupakan wujud dari Tuhan di alam semesta. Saat ini ketika jaman dikatakan berada dalam jurang kehancuran dalam pengelompokan jaman dala Hindu, tentu sangat sulit ditemukan seorang yang benar-benar mengabdikan diri sebagai "guru" 
yang sesungguhnya. Tidak dapat dipungkiri "guru" saat ini hanya menjadi sumber mata pencaharian, dan jauh dari makna sesungguhnya yang tertuang dalam pustaka suci Veda.

Menyepadankan "guru" dengan brahmana membawa pengertian bahwa "guru" memiliki kewajiban besar bukan hanya dalam bidang pengetahuan umum namun juga dalam pengetahuan spiritual yang nantinya dijadikan contoh oleh peserta didiknya. Dalam pustaka suci Mānava Dharmaśāstra sloka 57 menyebutkan bahwa terdapat dua belas macam sadhana yang terdiri dari: 1) dharma artinya seorang "guru" harus mencintai, membela dan melaksanakan kebenaran, 2) satya artinya seorang "guru" selalu berperilaku jujur, 3) tapa artinya sikap pengendalian diri dengan penuh ketenangan, 4) dama artinya selalu tenang dan damai, mampu menaklukan nafsu indrya dan mampu menasihati diri sendiri, 5) wimarsaritya artinya tidak dengki, tidak iri hati, tidak serakah dan tidak mementingkan diri sendiri, 6) Hrih artinya memili rasa malu, sopan santun dan rendah hati, 7) titiksa artinya sikap sadar dan tidak resah atau gusar, 8) anusuya artinya tidak berbuat tercela dan dosa, berhati mulia dan tidak pemarah, 9) yajna artinya korban suci melalui puja-bhakti, 10) Dana artinya sedekah yang dilakukan dengan tulus ikhlas, 11) dhrti artinya penyucian pikiran dan 12) ksama artinya pemaaf (Donder, 2008: 286-292).

Betapa mulianya seorang apabila saat ini masih terdapat "guru" yang memiliki pemahaman dan kesadaran bahwa dibalik tugasnya sebagai pengajar juga memiliki kewajiban lain yang harus selalu diimplementasikan dalam kehidupannya sehari-hari sebagai "guru". Dua belas sadhana yang tertuang dalam pustaka suci Mānava Dharmaśāstra idealnya menjadi pegangan utama oleh seorang "guru" dalam menjalankan kewajibannya yang nantinya akan membawa pada tingkatan "guru" yang benar-benar bijaksana. Predikat kehormatan yang diberikan kepada seorang "guru" tentunua tidak menyebabkan "guru" tersebut menjadi terlena dan mengangkat dada bahwa dirinya adalah orang yang terhormat, namun hal ini harus disadari menjadi beban dan wajib hukumnya untuk mempertanggungjawabkan beban tersebut.

Realita yang terjadi dijaman kali yuga, saat manusia diyakini memiliki kesadaran yang sangat minim dalam menjalankan kewajiban serta melakukan kebaikan terlihat pula pada kualitas "guru" dan pengajar baik dalam tingkat dasar dan perguruan tinggi juga mengalami berbagai kurangnya kesadaran dari tenaga pengajar. Hal ini dapat dilihat dari kurang mampunya seorang"guru" menguasai materi yang disampaikan, sehingga peserta didiknyapun menjadi bingung, apalagi dalam upaya mempelajari ajaran-ajaran yang tertuang dalam pustaka suci Hindu yang tentunya sebagai manusia harus memiliki "guru" yang benar-benar berkompeten. Tidak sedikit pula terdapat "guru" yang tidak menjalankan dua belas sadhana yang terdapat dalam pustaka suci Mānava Dharmaśāstra, misalnya masih banyak "guru" yang mudah terpancing emosi dan tidak terkontrol sehingga pengetahuan yang disampaikan tidak dapat diterima oleh peserta didik. Selain melanggar dari sadhana seorang "guru" hal ini tentu mengarahkan atau mempertontonkan suatu hal yang keliru dan tidak sesuai dengan apa yang menjadi kewajiban dari "guru" yang sesunguhnya.

Idealnya seorang "guru" adalah wajib mampu mengendalikan diri. Pengendalian diri sesungguhnya menjadi bagian penting untuk mengarahkan pemikiran pada arah yang positif, ketika pikiran positif, tentu segala hal termasuk 
perkataan dan perbuat yang keluar akan bersifat positif. Hal ini juga ditegaskan dalam pustaka suci Mānava Dharmaśāstra yaitu sebagai berikut:

Sāvitri mātrasaro'pi varam viprah suyantritah

Nāyantri tastri vedo'pi sarvaçi sarvavikrayi

(Mānava Dharmaśāstra II.118)

Terjemahan:

Seorang brahmana yang menguasai diri sepenuhnya, walaupun ia hanya tahu mantra Savitri saja, maka ia lebih baik dari pada orang yang mengetahui ketiga Veda tetapi tidak mampu menguasai diri, apalagi memakan segala macam makanan dan menjual segala macam barang (Pudja \& Rai Sudharta)

Sloka Mānava Dharmaśāstra II.118 ini memberikan gambaran betapa pentingnya seorang brahmana menguasai diri dalam hal ini mampu mengendalikan indrya-indya yang dimiliki sehingga benar-benar memiliki kejernihan hati yang nantinya juga akan berpengaruh terhadap penyampaian pengatahuan terhadap peserta didik. Ini menunjukan pengendalian indrya memang menjadi tugas manusia tanpa terkecuali seorang "guru" yang memiliki peranan serta menjadi panutan bagi banyak orang. Bagaimana mungkin seorang mampu menjadi "guru" yang bijaksana apabila mengendalikan dirinya saja belum mampu dilakukan. Seorang "guru" sejatinya berperan untuk mampu mengendalikan peserta didiknya dan membawa ke arah yang lebih baik.

Pengendalian diri menjadi kewajiban bagi setiap orang, tanpa terkecuali seorang "guru" yang menjadi panutan bagi peserta didiknya. Pengendalian diri tentunya bukan hal yang mudah, sebagai awal untuk dapat mengendalikan diri adalah mampu menguasai atau mengendalikan pikiran sebagai sumber utama setiap keinginan dari indrya-indrya manusia. Pikiran (manah) merupakan satu dari tiga bagian gerak yang harus disucikan sebagai manusia, hal ini tertuang dalam salah satu konsep Hindu yaitu trikaya parisuda. Tiga gerak yang harus disucikan ataupun dikendalikan (trikaya parisuda) ini menjadi hal dasar yang sangat penting untuk manusia dapat mencapai kebahagian hidup. Salah satu bagian dari trikaya parisuda adalah manacika parisuda (gerak pikiran).

Dalam upaya mengendalikan gerak pikiran tentunya terdapat hal-hal yang perlu dilakukan untuk dapat mengendalikan pikiran tersebut, diantanya: 1) tan engine/tan adengkia ri drwyaning len (tidak ingin/ tidak dengki kepada kepunyaan orang lain), 2) tan krodha ring sarwa satwa (tidak mudah marah terhadap semua makhluk), 3) mamituhwa ri hananing karmaphala (yakin sepenuhnya akan adanya hukum karmaphala). Sebagai dasar dalam upaya pengendalian pikiran, tiga hal ini menjadi pegangan setiap manusia untuk dapat mengendalikan pikiran yang menjadi sumber utama setiap keinginan (Ida Pedanda Kemenuh, 2012:3-4).

Ketiga dasar konsep di atas harus juga menjadi pegangan dasar seorang "guru" dalam memberikan pengetahuan kepada peserta didiknya. "guru" sebagai tauladan bagi seorang siswa memiliki kewajiban yang sangat tinggi dalam mengendalikan diri terutama mampu dalam mengendalikan pikiran. Ketika seorang "guru" mampu mengendalikan diri dan pikiran maka hal tersebut akan menjadi panutan dan juga contoh dalam setiap tindakan yang akan dilakukan oleh peserta didiknya. Secara teologis "guru" menjadi kunci utama dalam proses penyampaian pengetahuan sehingga mampu dimengerti, dan mampu diimplementasikan dalam kehidupan sehari-hari. 
Setelah mampu mengendalikan pikiran dan juga diri sendiri, sebagai manusia yang memiliki tugas sebagai seorang "guru" tidak akan lagi terbelenggu dengan materi. Sebagai manusia, saat ini tentu segala bentuk materi terkadang menjadi tujuan utama karena kita sebagai manusia tidak mampu mengendalikan indryaindrya yang selalu menginginkan sesuatu hal yang berlebihan. Sebagai umat manusia, dalah hal ini yang memiliki tugas sebagai "guru" harus mampu terlepas dari hal tersebut. Materi bukan menjadi tujuan utama dalam kewajiban sebagai "guru" namun namun upaya untuk mengarahkan siswa mendobrak dan keluar dari kebodohan itulah yang menjadi tujuan utama. Hal ini sesuai dengan pengertian "guru" yang berasal dari kata gunatitha dan rupavarjitha. Gunatitha artinya tidak terbelenggu oleh materi dan rupavarjitha artinya mampu menyeberangkan umat manusia dari samudra samsara. Jadi dapat disimpulkan bahwa "guru" adalah orang yang tidak terikat oleh belenggu materi dan mampu menyeberangkan umat manusia dari samudera kesengsaraan (Donder, 2008: 158).

Sedemikian rupa penjelasan arti kata "guru" yang tertuang dalam berbagai pustaka suci Hindu tentunya dapat dipahami bahwa "guru" sesungguhnya bukan hanya sebatas profesi mengajar, namun memiliki pertanggungjawaban yang sangat besar terhadap Tuhan karena "guru" merupakan wujud dari Tuhan pada alam semesta sebagai perantara sampainya ilmu pengetahuan yang bertujuan untuk membebaskan manusia dari kebodohan.

\section{SIMPULAN}

Pemahaman masyarakat tentang arti kata guru saat ini hanya berada pada sebuah profesi mengajar dimana kewajibannya mendidik siswa/siswi untuk memahami pengetahuan yang dimilikinya. Tidak sedikit guru saat ini hanya sekedar dalam menyampaikan pengetahuan, pemahaman peserta didik tidak lagi menjadi tujuan utama dalam pembelajaran. Terkadang saat ini banyak guru yang hanya memikirkan hak yang diperoleh dari pemerintah namun tidak menjalankan kewajibannya dengan sungguh-sungguh dalam mencerdaskan peserta didik.

Arti kata "guru" sesungguhnya memiliki cakupan yang lebih dalam dibandingkan hanya dimaknai sebagai sebuah pekerjaan. Seorang "guru" sejati tidak mementingkan diri sendiri dan juga memberikan pengetahuan secara penuh bahkan menyerahkan dirinya sebagai wujud dari pengetahuan itu sendiri. Secara teologi, dalam pandangan Hindu kedudukan "guru" memiliki tingkatan yang sangat tinggi, "guru" disimbolkan sebagai symbol kepala dalam tubuh manusia yang artinya "guru" bukanlah orang biasa, namus seseorang yang mampu memiliki pandangan penuh dalam memahami serta menyampaikan pengetahuan.

Terdapat berbagai kisah kehebatan dan kemuliaan "guru" yang tertuang dalam pustaka suci Hindu sebagai pedoman menjalankan kehidupan. Hingga saat ini arti kata "guru" mengalami pergesaran yang justru menyempitkan bahkan merendahkan "guru" itu sendiri. Kewajiban utama seorang "guru"dalam kajian teologi Hindu adalah mampu menjalankan konsep-konsep ketuhanan yang idealnya harus dimiliki sebagai pegangan seorang "guru" sehingga pengetahuan yang dimiliki dapat disampaikan dengan jelas dan tentunya dapat dimengerti oleh peserta didik.

Hal terpenting yang harus dipahami dan dijadikan dasar oleh seorang "guru" adalah tidak terikat oleh belenggu materi yang artinya benar-benar menyampaikan pengetahuan dengan tulus iklas tanpa mengharapkan apapun, dan juga harus 
memiliki kemampuan yang memadai sehingga mampu mengarahkan peserta didiknya terlepas dari kebodohan (avidya) sehingga tujuan utama sebagai manusia Hindu dapat terpacai.

\section{DAFTAR PUSTAKA}

Aripta Wibawa, Made. Siapakah Yang Disebut Guru (Suatu Kajian Theologis dan Sosiologis). Denpasar: Panakom

Dewanto. 2005. Veda Śruti Rg Veda Samhitā (Sākala Śākhā) Resensi Dari Śākala. Surabaya: Paramita

Donder, I Ketut. 2007. Kosmologi Hindu. Surabaya: Paramita.

Donder, I Ketut. 2008. Ācārya Sista Guru dan Dosen yang Bijaksana. Surabaya: Paramita.

Ida Pedanda Kemenuh. 2012. Trikaya Parisuda \& Catur Prawerti. PT Mabhakti.

Pudja, G., Rai Sudharta, Tjokorda. 1973. Manava Dharaçastra. Jakarta: Departemen Agama RI

Roestiyah. 2005. Strategi Belajar Mengajar. Jakarta: Bina Aksara

Suhardana, K.M. 2013. Ensklopedia Hindu Jilid II D-M. Surabaya: Paramita

Undang-Undang Republik Indonesia No. 20 Tahun 2003 Tentang Sistem PendidikanNasional:sipuu.setkab.go.id

Undang-Undang Republik Indonesia No.14 Tahun 2005 Tentang Guru dan Dosen: jdih.kemenkeu.go.id

Warsono.2017. Guru: Antara Pendidik, Profesi dan Aktor Sosial. The Journal of Society \& Media. Jurnal Universitas Negeri Surabaya. 